\title{
Ownership Structure on Dividend Policy and Its Impact on Firm Value
}

\author{
Jacobus Widiatmoko ${ }^{1}$ \\ Faculty of Economics and Business \\ UniversitasStikubank Semarang, Indonesia \\ jwidiatmoko@edu.unisbank.ac.id \\ Achmad Badjuri ${ }^{2}$ \\ Faculty of Economics and Business \\ UniversitasStikubank Semarang, Indonesia \\ badjuri@edu.unisbank.ac.id
}

\author{
Moch. Irsad \\ Faculty of Economics and Business \\ UniversitasStikubank Semarang, Indonesia \\ moch.irsad@edu.unisbank.ac.id \\ AgungAnugerahAdhipratama ${ }^{4}$ \\ Faculty of Economics and Business \\ UniversitasStikubank Semarang, Indonesia \\ anugerah.agung20@edu.unisbank.ac.id
}

\begin{abstract}
The purpose of this study is to examine the effect of share ownership structure on dividend policy and its impact on firm value. Ownership structure is proxied by managerial ownership, institutional ownership, and ownership concentration. The research data were obtained from manufacturing companies listed on the Indonesia Stock Exchange (BEI) 2016-2018 using purposive sampling method of selecting samples. The results of hypothesis testing using multiple regressions indicate that institutional ownership and ownership concentration have a positive effect on dividend policy,while managerial ownership has no effect. The results also show that dividend policy has a positive effect on firm value. As predicted, profitability and leverage as control variables have an effect on dividend policy and firm value.
\end{abstract}

Keywords: ownership structure, dividend policy, firm value, control variables

\section{INTRODUCTION}

The long-term goal to be achieved by establishing a company is to maximize its value [1]. Maximizing firm value also means increasing the welfare of its owners, because an increase in firm value will increase their income through an increase in share prices. A high share price will ultimately increase the value of the company, which indicates an increase in the welfare of shareholders.

Company value is a market perception that comes from investors, creditors and other stakeholders on the success achieved by the company in managing the resources it has in the company's stock price [2]. One aspect of determining the value of the company is the stock market price, because the stock market price reflects the investor's assessment of the total equity held. The higher the share price the higher the shareholder's profits, therefore this is the situation that investors will be interested in [3].

The achievement of the company's long-term goals is manifested in short-term achievements, namely the acquisition of profits in each of its operations within a certain period. Increasing profits will ensure the company's long-term survival. Profits earned by the company on the one hand can be used to improve the welfare of company owners, on the other hand it is a source of internal funding for the development of the company. The policy of deciding whether the profits earned by the company will be distributed to shareholders as dividends or will be retained in the form of retained earnings for future investment financing is known as dividend policy.

Dividend policy will have an impact on the size of the company's retained earnings which is a source of internal company funding that will be used to develop the company in the future [4]. Dividend policy refers to a set of rules determined by the company in determining how much portion of the profits to be distributed to shareholders [5]. High dividend distribution can increase company value, through the perception that high dividends increase the welfare of shareholders. However, dividends that are too large will make it difficult for management to finance company investment opportunities because internal sources of funds are limited. This forces management to look for alternative sources of funding if they want to take investment opportunities, and this alternative may be more costly. Therefore, dividend policy is also one of the sources of conflict between the company owner (principal) and company management as agents, which is known as agency conflict.

So that the determination of the size of the profit distributed to shareholders (dividend policy) does not become the monopoly of certain parties in the company, it is necessary to have a good corporate governance mechanism. The governance mechanism can be determined based on the share ownership structure, so that there is control over decision making regarding dividend policy. Ownership structures that can be used as a control and monitoring mechanism are institutional ownership, managerial ownership and ownership concentration

Managerial ownership is also a means of reducing agency conflict. Thus the decisions to be taken regarding dividend policy are accurate policies that can support the increase in company value. The more the company focuses on increasing managerial ownership, the more it aligns the position of managers with 
shareholders, which is expected to reduce manager behavior in consuming excessive facilities [6]. The existence of institutional ownership can reduce agency problems that exist in the company. Institutional ownership is a share ownership by a company from an institution or other body. The more companies increase institutional ownership, the more it shows the size of share ownership by institutional parties which can function to reduce opportunistic actions by managers through better monitoring mechanisms. The supervisory function can also be created with concentrated ownership because its existence can further increase the decision to pay dividends to shareholders. Concentrated ownership pays more attention to oversight of company decisions with the aim of protecting its investment [7]. Ownership concentration describes how and who has control over the whole or a large part of the ownership of the company as well as all or most of the holders of control over the business activities of a company [8].

Apart from being influenced by the ownership structure, dividend policy is also influenced by company characteristics, including the ability to generate profits (profitability) and leverage. Related to profitability, research conducted by [9] stated that the higher the profitability ratio, the higher the dividend distribution policy. Conversely, leverage is a source of financing for company assets obtained by using loan or debt funds. If the company's debt is higher, then the company's profits will be used to pay off debt so that the company's net profit will also decrease. This causes the possibility of the distribution of dividends distributed to shareholders to decrease. [10] found that leverage has a negative and significant effect on dividend policy (Dividend Payout Ratio).

Based on the above thinking, the ownership structure can influence the dividend policy adopted by the company, which in turn will affect the company's value. However, in empirical testing, this theoretical path is not always proven. Research conducted by [11] [12] [13] and [14] related to the influence of ownership structure and dividend policy show different results.

Research on the effect of dividend policy on firm value has been widely conducted. [15] [16] both state that the dividend policy proxied as DPR has a positive and significant effect on firm value. Likewise, [17] and [18] suggest the effect of dividend policy on firm value. [19] research results state that dividend policy has a negative and insignificant effect on firm value. Meanwhile, the results of research by [20] state that dividend policy has a positive and significant effect on firm value.

Based on this, this study empirically examines the flow of thought of the effect of ownership structure on dividend policy and its impact on firm value with the control variables of profitability and leverage.

\section{METHODS}

\section{A. Population and sample}

The population in this study are all manufacturing companies listed on the Indonesia Stock Exchange (BEI) in the 2016-2018 observation year. The sample selection method used was purposive sampling, with the criteria 1) publishing annual financial reports for the period 2016-2018, 2) having complete data. Based on these criteria, 127 data were obtained.

\section{B. Operational Definition and Variable Measurement}

The variables in this study consist of endogenous variables, namely firm value, the mediating variable, namely dividend policy and ownership structure as independent variables which include managerial ownership, institutional ownership, and ownership concentration. Firm value is measured by tobins'q, which is the ratio between stock market value plus debt divided by total assets [21]. Dividend policy is measured by the dividend payout ratio (DPR), which is calculated by dividing dividends per share by earnings per share. Managerial ownership is measured by the ratio between the number of shares owned by the manager and the total shares outstanding, institutional ownership is measured by the ratio between the number of shares owned by the institution and the number of shares outstanding, and ownership concentration is measured by the ratio between the largest share ownership and the number of shares outstanding [22]. This study uses two control variables, namely profitability as measured by return on assets (ROA) and leverage which is the ratio between debt and assets [23].

\section{Data Analysis Techniques}

The hypothesis in this study was tested using two multiple linear regression models, with the following equation:
$\mathrm{DPR}=\alpha+\beta 1$ ManOwn $+\beta 2$ InstOwn + $\beta 3$ ConsOwn $+\beta 4$ Prof $+\beta 5 \mathrm{Lev}+\varepsilon$

Tobin's $\mathrm{Q}=\alpha+\beta 1$ ManOwn $+\beta 2$ InstOwn + $\beta 3$ ConsOwn $+\beta 4$ DPR $+\beta 5$ Prof + $\beta 6 \operatorname{Lev}+\varepsilon$

Where:

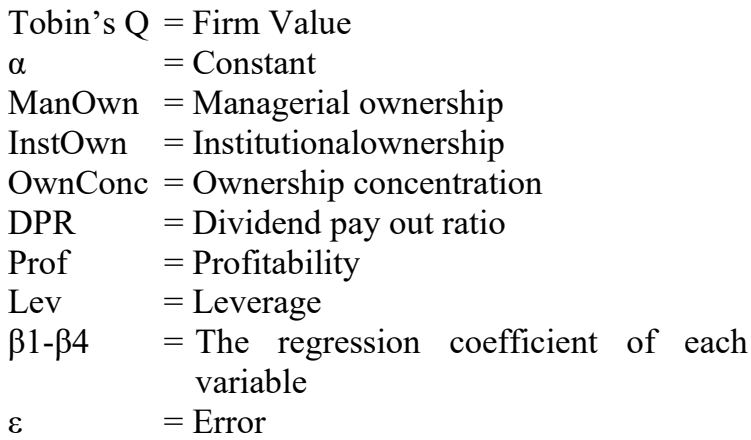

\section{RESULTS AND DISCUSSION}

\section{A. Results of Model Testing}

Both models in this study have passed the residual normality test and classic assumptions. The classical assumption test consists of multicollinearity, autocorrelation and heteroscedasticity, which arerequirements for using ordinary least square (OLS) regression. The results of testing Model 1 and Model 2 are presented in Table 1 
Table 1

Summary of Testing Results for Models $1 \& 2$

\begin{tabular}{|l|r|c|r|c|}
\hline Description & \multicolumn{4}{|c|}{ Dependent Variables } \\
\hline & Model 1 (DPR) & \multicolumn{2}{c|}{ Model 2 (Firm Value) } \\
\hline & Coefficient & Sig & Coefficient & Sig \\
\hline ManOwn & -.002 & .152 & -.002 & .730 \\
\hline InstOwn & .002 & .032 & -.002 & .548 \\
\hline OwnCons & .215 & .043 & -.003 & .993 \\
\hline DPR & - & - & .157 & .023 \\
\hline Prof & 1.252 & .000 & 15.643 & .000 \\
\hline Lev & -.128 & .030 & -2.118 & .000 \\
\hline Adjusted R & .212 & & .856 & \\
\hline F-test & 6.325 & & 102.432 & \\
\hline Sig. & .000 & & .000 & \\
\hline
\end{tabular}

Based on the results of the F statistical test in Table 1 , models 1 and 2 each have a number of 6,325 and 102,432 with a significance level of 0,000 . It can be concluded that models 1 and 2 meet the goodness of fit model. Based on Table 1, it can also be seen that the value of Adjusted R Square Model 1 and 2 respectively shows a number of 0.212 or $21.2 \%$ and 0.856 or $85.6 \%$. This means that in Model $1,21.20 \%$ of the variation in the dividend payout ratio can be explained by all independent variables in Model 1, while the remaining $78.8 \%$ is explained by other variables that have not been considered in this study. In equation 2 , $85.6 \%$ of the variation in firm value can be explained by the independent variables in Model 2, while the remaining $14.45 \%$ is explained by other variables outside of this research model.

\section{B. Hypothesis Testing Results}

Based on the results of Model 1 testing in Table 1, it can be seen that the managerial ownership variable has a beta value of -0.002 and a significance value of 0.152 , so that $\mathrm{H} 1$ which states that managerial ownership has a positive effect on dividend policy is rejected. This means that share ownership by the board of directors and managers does not affect the size of the proportion of profits that will be distributed to shareholders. This finding does not support the claim that the higher the managerial ownership will increase the proportion of profit distributed as dividends, because the greater the share ownership by the manager will reduce agency conflicts, resulting in harmony between managers and owners who are also managers. This finding is not in line with the results of research by [11] and [12].

The institutional ownership variable has a beta coefficient value of 0.002 with a significance level of 0.032 , so that $\mathrm{H} 2$ which states that institutional ownership has a positive effect on dividend policy is received. The results of this study indicate that the greater the shares owned by the institution, the greater the motivation of the owners to share profits as dividends. This condition shows that dividend policy is still a monitoring mechanism that can reduce agency conflicts. The results of this study support the findings of [13], and [24], which prove that more higher institutional ownership the higher the dividends distributed.

The ownership concentration variable has a beta coefficient value of 0.215 with a significance level of
0.043. This means that ownership concentration has a significant positive effect on dividend policy so that $\mathrm{H} 3$ is accepted. In accordance with agency theory, the existence of concentrated ownership is a mechanism that can be taken to reduce agency conflicts, both between owners and agents, and between owners themselves. The existence of a dominant owner is able to supervise the agent more intensively so that it can direct the agent to be loyal to the main goal of the company, namely maximizing the value of the company through ways of increasing profits, and increasing the share of profits that are distributed to shareholders. For management, an increase in profits and dividends can also be used as a good signal for the company's performance. The results of this study support the results of research conducted by [7] and [22].

Based on the information in Table 1, it can be seen that the dividend policy variable (DPR) has a beta coefficient of 0.157 with a significance level of 0.023 . This shows that the dividend policy has a positive effect on firm value, so that $\mathrm{H} 4$ is accepted. This result is in accordance with the signal theory which states that dividends are one of the signals that have a good effect in building a company performance image. Dividend policy is an expensive signal because it is not easy for other companies to copy it and only wellperforming companies can do so. Therefore, various efforts have been taken by the company to consistently distribute dividends. The results of this study support the results of previous studies by [15] [16] which state that dividend policy proxied as DPR has a positive effect on firm value.

Based on the results of Model 2 testing in Table 1, it can be seen that dividend policy has a positive effect on firm value, while ownership structure does not directly affect firm value. Ownership structure proxied with ownership concentration has an indirect effect on firm value, namely through dividend policy. The higher the concentration of ownership, the higher the dividend policy (DPR), the higher the DPR, the higher the firm value. As expected, the two control variables in Model 1, namely profitability have a positive effect on dividend policy and leverage has a negative effect on dividend policy. The same results consistently occur in Model 2.

\section{CONCLUSION}

This study examines the effect of ownership structure on dividend policy and its impact on firm value. Ownership structure includes managerial ownership, institutional ownership and ownership concentration. The results of the Model 1 test show that institutional ownership and ownership concentration have a positive effect on dividend policy, while managerial ownership has no effect. As expected, two control variables, namely profitability and leverage, have a consistent effect on Models 1 and 2. Profitability has a positive effect on dividend policy and leverage has a negative effect on dividend policy. The test results in model 2 show that only dividend policy has a positive and significant effect on firm 
value. This study shows that the ownership structure proxied by ownership concentration has an indirect effect on firm value, namely through dividend policy.

Regardless of the contribution made, this study has several weaknesses that require improvement in future research. These weaknesses include limited data because not all companies have managerial ownership data and pay dividends. This condition is the cause of many variables that are not proven in this study. Future research could expand the population of all dividendpaying firms or use board structure and activity as a proxy for corporate governance.

\section{ACKNOWLEDGMENT}

Researchers would like to thank the rector of the University of Stikubank Semarang for funding the research and participation in this call for paper.

\section{REFERENCES}

[1] Farida, Ramadhan, A., \& Wijayanti, R. (2019). The Influence of Good Corporate Governance and Corporate Social Responcibility on Firm Value: Evidence from Indonesia. International Journal of Economics and Financial Research. Dipetik 12 2019, 11, dari https://doi.org/10.32861/ijefr.57.177.183

[2] Tambunan, M. C., Saifi, M., \& Hidayat, R. R. (2017, Desember 1). Pengaruh Good Corporate Governance terhadap Nilai Perusahaan. Jurnal Administrasi Bisnis (JAB). Dipetik http://administrasibisnis.studentjournal.ub.ac.id/index.php/ja b/article/view/2181/2579

[3] Widyaningsih, D. (2018). Kepemilikan Manajerial, Kepemilikan Institusional, Komisaris Independen, Serta Komite Audit Pada Nilai Perusahaan Dengan Pengungkapan CSR sebagai Variabel Moderating dan Firm Size sebagai Variabel Kontrol. Jurnal Akuntansi dan Pajak. Dipetik Desember $\quad 14, \quad 2019$, dari http://jurnal.stieaas.ac.id/index.php/jap

[4] Uwigbe, U. et. Al (2012). Dividend Policy and Firm Performances: A study of Listed Firm in Nigeria. Accounting and Management Information Systems, 11 (3): pp. $442-454$

[5] Agus, Sartono. 2011. Manajemen Keuangan Teori dan Aplikasi.Yogyakarta: BPFE.

[6] Warapsari, A. A., \& Suaryana, I. G. (2016, 09). Pengaruh Kepemilikan Manajerial dan Kepemilikan Institusional terhadap Nilai Perusahaan dengan Kebijakan Utang sebagai Variabel Intervening. E-Jurnal Akuntansi Universitas Uyudana. Dipetik $02 \quad 2020, \quad$ dari https://ojs.unud.ac.id/index.php/Akuntansi/article/view/2097 4

[7] Ullah, H. A. Fida and S. Khan. (2012). The Impact of Ownership Structure on Dividend Policy from Emerging Markets KSE-100 Index Pakistan. International Journal of Business and Social Science, 3 (9): pp. 298-307

[8] Shleifer, A. and Vishny, R.W. (1986), "Large shareholders and corporate control", Journal of Political Economy, Vol. 94 No. 3, pp. 461-488.

[9] Ferris, S. P., Sen, N. and Yui, H. P. (2006). God Save the Queen and Her Dividends: Corporate Payouts in the United Kingdom. The Journal of Business, vol. 79, issue 3, 11491174. http://dx.doi.org/10.1086/500672

[10] Asad, M., \& Yousaf, S. (2014). Impact of leverage on dividend payment behavior of Pakistani Manufacturing Firms. International Journal of Innovation and Applied Studies, 6(2), 216.

[11] Mehrani, S., Moradi, M., and Eskandar, H. (2011). Ownership Structure and Dividend Policy: Evidence from Iran. African Journal of Business Management, 5 (17): pp. 7516-7525

[12] Thanatawee, Yordying. (2013). Ownership Sructure ad Dividend Policy: Evidence from Thailand. International Journal of Economics and Finance, 5 (1): pp.121-132
[13] Lucyanda, J. and Lilyana. 2012. Pengasuh free Cash Flow dan Struktur Kepemilikan terhadap Dividend Payout Ratio. Journal Dinamika Akuntansi. Vol 4 (2): pp.129-138

[14] Afza, T. and H.H. Mirza. (2010). Ownership Structure and Cash Flows as Determinants of Corporate Dividend Policy in Pakistan. International Busines Research, 3 (3): pp. 210221

[15] Senata, Maggee. (2016). Pengaruh Kebijakan Dividen terhadap Nilai Perusahaan yang Tercatat pada Indeks LQ-45 Bursa Efek Indonesia. Jurnal Wira Ekonomi Mikroskill, 6(1)

[16] Mardiyati, U.. Ahmad. G N.. Putri, R.. 2012, Pengaruh Kebijakan Devidend, Kebijakan Hutang, dan Profitabilitas terhadap Nilai Perusahaan Manufaktur yang Terdaftar di Bursa Efek Indonesia (BEI) Periode 2005-2010, Jurnal Riset Manajemen Sains Indonesia (JRMSI), volume 3 nomor 1 , halaman $1-17$

[17] Olweny, T. (2012). Dividend Announcement and Firm Value: A Test of Semi Strong Form of Efficiency at the Nairobi Stock Exchange. Asian Social Science. Dipetik 02 2020, dari https://www.semanticscholar.org/paper/DividendAnnouncement-and-Firm-Value\%3A-A-Test-of-ofOlweny/62587584ee49df90b9fa4c7d8ee2e59dd34959a1

[18] Ali, H. dan Miftahurrohman. (2014). pengaruh Struktur Kepemilikan Saham, Kebijakan Dividen, dan Kebijakan Utang terhadap Nilai Perusahaan (studi pada Perusahaan yang Terdaftar di BEI). Jurnal Etikonomi, 13 (2): 148-163

[19] Ayem, Sri, dan Ragli Nugroho. (2016). Pengaruh Profitabilitas, Struktur Modal,Kebijakan Deviden, dan Keputusan Investasi Terhadap Nilai Perusahaan. Jurnal Akuntansi. 4(1): pp.31-39.

[20] Tahu, G. P., \& Susilo, D. D. (2017). Effect of Liquidity, Leverage and profitability to The Firm Value (Dividend Policy as Moderating Variable) in Manufacturing Company of Indonesia Stock Exchange. Research Journal of Finance and Accounting. Diambil kembali dari www.iiste.org

[21] Setiawan, A. (2016). Pengaruh Corporate Governance terhadap Kinerja Keuangan Perusahaan. Jurnal Sistem Informasi, Keuangan, Auditing, dan Perpajakan, 1 No 1. Diambil kembali dari http://jurnal.usbypkp.ac.id/index.php/sikap

[22] Widiatmoko, J. and M.G. Kentris Indarti. (2019). Book Tax Differences, Operating Cash Flow,Leverageand Earning Persistence in Indonesia Manufacturing Companies. Jurnal Dinamika Akuntansi 11 (20): pp.151-159

[23] Sumartha, E. (2016). Pengaruh Struktur Kepemilikan Terhadap Kebijakan Dividen Pada Perusahaan Manufaktur. Jurnal Economia 12(2):167

[24] Kurniawati, L., Manalu, S. dan Octavianus, R.J.N. (2015). Pengaruh Kepemilikan Institusional terhadap kebiajakan Dividan, dan Harga Saham. Jurnal Manajemen, 15 (1): pp. $59-73$ 